\title{
A variation of vasculopathies in a patient with mild pulmonary artery hypertension
}

\author{
Takao Kato, Takamasa Kitajima, Moriaki Inoko
}

Department of Cardiovascular Medicine, The Tazuke Kofukai Medical Research Institute Kitano Hospital, Osaka, Japan

\section{Correspondence to}

Dr Takao Kato,

takao-kato@kitano-hp.or.jp

\section{DESCRIPTION}

A 66-year-old woman with a 2-year history of rheumatoid arthritis (RA) that was treated with prednisolone was referred to our hospital due to a slight shortness of breath with normal vasculatures (figure 1A,B) and a small coin lesion (figure 1C,D). An estimated pulmonary artery pressure on echocardiography (figure 1E) of $44 \mathrm{~mm} \mathrm{Hg}$ that increased to $65 \mathrm{~mm} \mathrm{Hg}$ after 6 months. The mean pulmonary arterial pressure (PAP) was $37 \mathrm{~mm} \mathrm{Hg}$ (figure 2) without a shuntvitium, the mean pulmonary capillary wedged pressure was $10 \mathrm{~mm} \mathrm{Hg}$, and the calculated pulmonary vascular resistance (PVR) was increased to $376 \mathrm{dyn} /\left(\mathrm{s} / \mathrm{cm}^{5}\right)$. Because perfusion scintigraphy showed no abnormalities without clinical signs of systemic lupus erythematous, mixed connective tissue disease or systemic scleroderma, we diagnosed her as idiopathic pulmonary artery hypertension (IPAH). Administration of bosentan $(125 \mathrm{mg})$ for 1 month improved her symptom and decreased the PAP and PVR to $27 \mathrm{~mm} \mathrm{Hg}$ and $290 \mathrm{dyn} /\left(\mathrm{s} / \mathrm{cm}^{5}\right)$, respectively. Because the coin lesion increased in size, right upper lobe was resected 2 months later (figure $3 \mathrm{~A}$ ), which revealed a granulomatous lesion with Cryptococcus spp. Although normal pulmonary arteries were also observed, medial hypertrophy, intimal thickening (figure 3B,C), microthrombosis (arrowheads; figure $3 \mathrm{~B}, \mathrm{D}$ ), and few plexiform lesions (figure $3 \mathrm{E}$ ) were observed in the same field, indicating that a variation was observed in a patient with mild $\mathrm{PAH},{ }^{1}$ as well as severe PAH in autopsy or explantation cases. ${ }^{2}$

Since there were few reports ${ }^{3}$ and clinical signs, we could not conclude whether the RA caused $\mathrm{PAH}$, a very rare case or IPAH was coincidentally observed in a patient with RA.

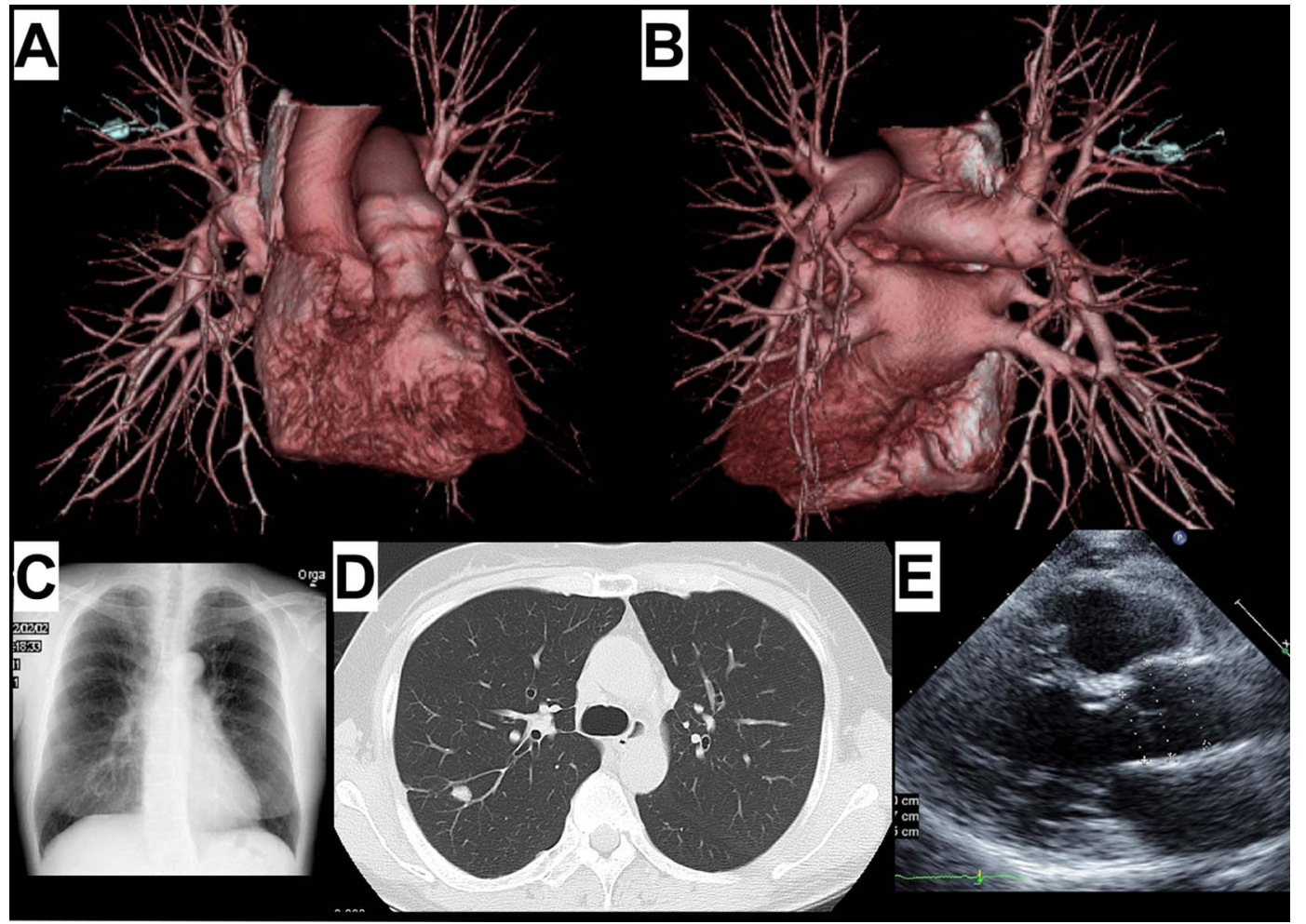

Figure 1 (A and B) Three dimensional reconstraction image of contrast-enhanced CT angiography. Anterior (A). Posterior (B). (C) A chest X-ray at admission. (D) Coin lesion in CT scans. (E) Echocardiography.
To cite: Kato T, Kitajima T, Inoko M. BMJ Case Rep Published online: [please include Day Month Year] doi:10.1136/bcr-2013200068 
Right heart catheterization

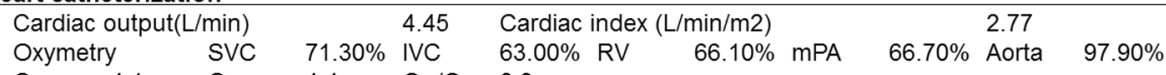

$\begin{array}{llllll}\text { Qp } & 4.1 & \text { Qs } & 4.4 & \text { Qp/Qs } & 0.9\end{array}$

Echocardiography (transthoracic)

\begin{tabular}{|c|c|c|c|c|c|c|c|}
\hline LVDd (mm) & 37 & LVDs (mm) & 25 & $64 \%$ & IVSTd & $(\mathrm{mm})$ & PWTd $(\mathrm{mm})$ \\
\hline $\operatorname{LAD}(\mathrm{mm})$ & 28 & LAVI (ml/m2) & 16 & $E(\mathrm{~m} / \mathrm{sec})$ & 0.72 & $A(\mathrm{~m} / \mathrm{sec})$ & 0.75 \\
\hline TRPG & & RVOT Act/ET & 0.23 & TAPSE $(\mathrm{mm})$ & 20.8 & Tei index (RV) & 0.38 \\
\hline
\end{tabular}

Shunt none

$\begin{array}{rlllllll}\text { Laboratory findings } \\ \text { Anti-CCP-Ab } & 123 & \text { RF } & 55 & \text { ANA } & 40 \text { (speckled) } & \text { U1-RNP-Ab } & \text { negative }\end{array}$

Anti-scl-Ab negative Anti-Centromere-Ab negative $\mathrm{BNP}(\mathrm{pg} / \mathrm{ml}) \quad 55$

Physical activity

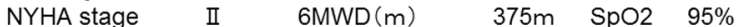

$\begin{aligned} \text { Respiratory function test } & & & \\ \% \text { VVC } 122.70 \% & \text { FEV1.0\% } & 74.90 \% & \% \text { DLCO } 94.10 \%\end{aligned}$

SVC; superior vena cava, IVC; inferior vena cava, RV; right ventricle, MPA; main pulmonary artery,

Qp; pulmonary flow, Qs; systemic flow, LVDd diastolic left ventricular dimension, LVDs; systolic LV dimension,

EF; ejection fraction, IVSTd; diastolic inetrventricular septal thickness, PWTd; diastolic posterior wall thickness,

$L A D$; left atrium diameter, LAVI; left atrium volume index, TRPG; tricuspid regurgitation pressure gradient,

RVOT Act/ET; right ventricular outlet tract acceleration time/ ejection time, TAPSE; Tricuspid Annular Plane Systolic Excursion,

$\mathrm{RV}$; right ventricle, CCP; citrullinated protein, RF; Rheumatic factor, ANA; antinuclear antigen, .BNP; brain natriuretic peptide,

NYHA; New York Heart Association, 6MWD; 6-minute walk distance, SpO2; blood oxygen saturation, VC; vital capacity,

FEV1.0; expiratory volume after 1.0 second, DLCO; diffusing capacity for carbon monoxide.

Figure 2 Details of right heart catheterisation, laboratory findings, physical activity and respiratory function testing.

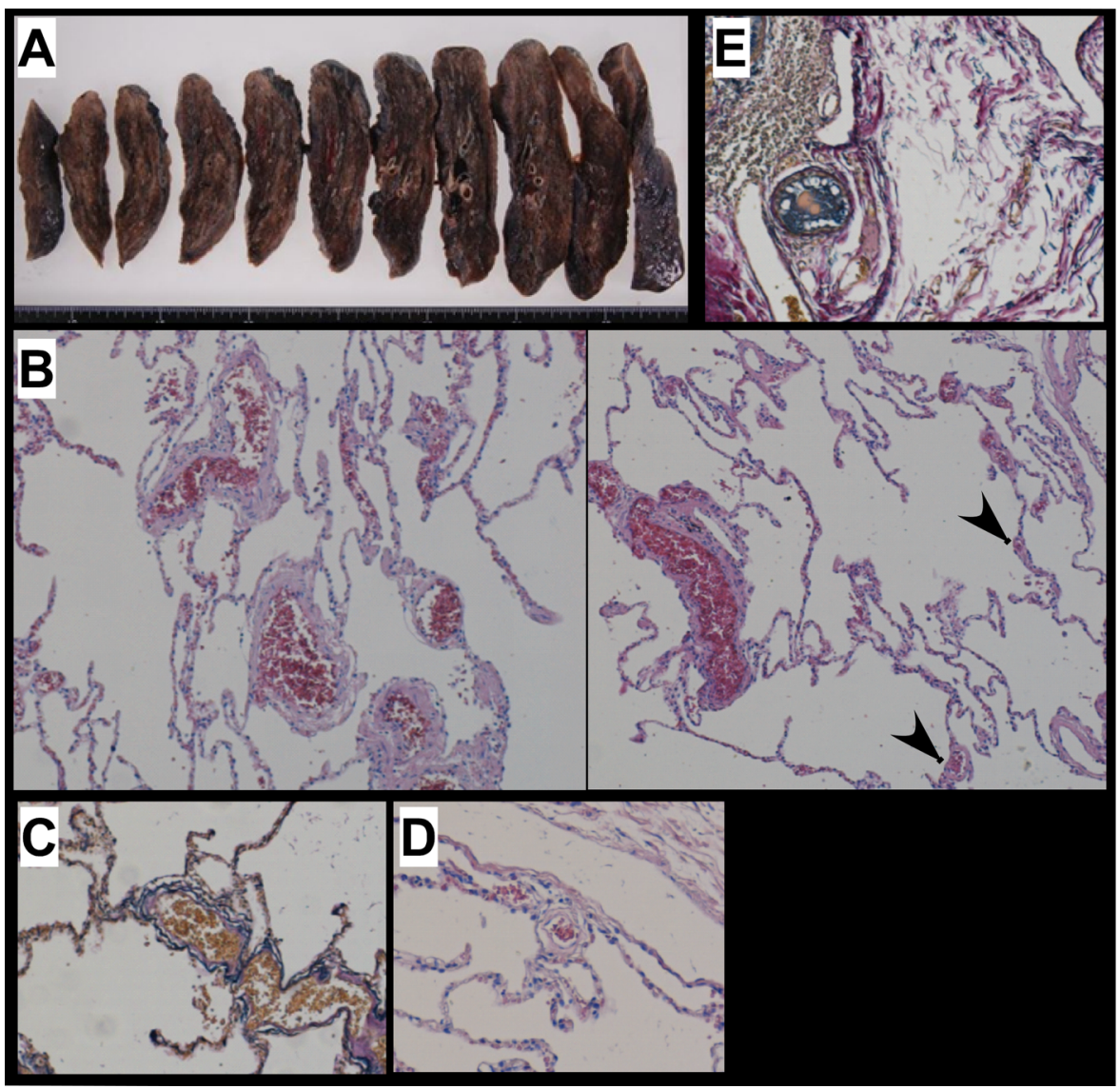

Figure 3 (A) Macroscopic examination of resected lung. (B) Medial hypertrophy, intimal thickening and microthrombosis (arrowheads) were observed by H\&E stainings. In the same field, normal pulmonary arteries were also observed. (C) Medial hypertrophy by elastic-Van Gieson (EVG) staining. (D) Microthrombosis. (E) A plexiform lesion by EVG staining. 


\section{Learning points}

- Pathological lesions in the pulmonary artery hypertension (PAH) are thought to belong to a similar spectrum in extension and distribution; however, a variation in the lesions was observed in a patient, even if it is very mild, as previously reported Wagenvoort, $1970{ }^{4}$

- Medial hypertrophy, intimal thickening, microthrombosis and a few plexiform lesions were observed and normal pulmonary arteries were also observed in the same field.

- Pulmonary hypertension with rheumatoid arthritis (RA) is rare, therefore we could not conclude whether the RA caused $\mathrm{PAH}$, a very rare case, or idiopathic pulmonary artery hypertension was coincidentally observed in a RA patient.
Contributors TK wrote the manuscript and RN and MI were supervisors of the manuscript.

Competing interests None.

Patient consent Obtained.

Provenance and peer review Not commissioned; externally peer reviewed.

\section{REFERENCES}

1 Strange G, Playford D, Stewart S, et al. Pulmonary hypertension: prevalence and mortality in the Armadale echocardiography cohort. Heart 2012;98:1805-11.

2 Yi ES, Kim H, Ahn H, et al. Distribution of obstructive intimal lesions and their cellular phenotypes in chronic pulmonary hypertension. A morphometric and immunohistochemical study. Am J Respir Crit Care Med 2000;162:1577-86.

3 Udayakumar N, Venkatesan S, Rajendiran C. Pulmonary hypertension in rheumatoid arthritis-relation with the duration of the disease. Int I Cardiol 2008;127:410-2.

4 Wagenvoort CA. The pathology of primary pulmonary hypertension. J Pathol 1970;101:Pi.

Copyright 2013 BMJ Publishing Group. All rights reserved. For permission to reuse any of this content visit http://group.bmj.com/group/rights-licensing/permissions.

BMJ Case Report Fellows may re-use this article for personal use and teaching without any further permission.

Become a Fellow of BMJ Case Reports today and you can:

- Submit as many cases as you like

- Enjoy fast sympathetic peer review and rapid publication of accepted articles

- Access all the published articles

- Re-use any of the published material for personal use and teaching without further permission

For information on Institutional Fellowships contact consortiasales@bmjgroup.com

Visit casereports.bmj.com for more articles like this and to become a Fellow 